\title{
Pembelajaran PPKn Dalam Resonansi Kebangsaan dan Globalisasi
}

\author{
Putu Ronny Angga Mahendra ${ }^{1 *}$ \\ ${ }^{1}$ Program Studi PPKn, FKIP, Universitas Dwijendra, Denpasar
}

\section{A R T I C L E I N F O}

Article history:

Received 31 Oktober 2018

Accepted 30 November

2018

Available online 31

Desember 2018

Kata Kunci:

Resonansi Kebangsaan;

Globalisasi; PPKn

Keywords:

National Resonance

Globalization; PPKn

\begin{abstract}
A B S T R A K
Globalisasi menghadirkan tatanan baru dunia yang lebih terbuka akan informasi dan modernisasi. Globalisasi tidak hanya memberikan nilai positif bagi kehidupan manusia, tetapi juga tidak lepas dari pengaruh negatif yang dibawanya dalam berbagai sisi kehidupan manusia. Dihadapkan pada persoalan globalisasi, tulisan ini memberikan potret bagaimana implementasi. Pancasila sebagai sumber nilai bagi adanya hukum dan kepribadian bangsa Indonesia di tengah-tengah pusaran globalisasi. Pancasila dalam pusaran globalisasi harus tetap menjadi prinsip dan ideologi kebangsaan yang mampu membangkitkan keyakinan dan rasa percaya diri bahwa kita adalah bangsa yang terhormat di dunia bukan sebaliknya. PPKn dalam tujuannya bagaimana mampu menghasilkan sifat dan perilaku warga yang baik dan bertanggung jawab serta bermanfaat bagi masyarakat, bangsa dan Negara. Salah satu cara dalam mencapai tujuan ini adalah dengan memanfaatkan suatu identitas
\end{abstract} yang ada dalam suatu masyarakat dalam pembelajaran. Keberadaan suatu identitas bangsa akan ditopang oleh kebudayaan daerahnya masing-masing, dan kebudayaan adalah salah satu pembentuk karakter masyarakat.

\begin{abstract}
A B S T R A C T
Globalization presents a new order of a more open world of information and modernization. Globalization not only provides positive value for human life but also can not be separated from the negative influence it carries on various sides of human life. Faced with the problem of globalization, this paper provides a portrait of how it is implemented. Pancasila as a source of value for the existence of the law and personality of the Indonesian nation in the midst of the vortex of globalization. Pancasila in the vortex of globalization must remain a national principle and ideology that can evoke confidence and confidence that we are a respectable nation in the world, not the other way around. PPKn in its aim how to be able to produce excellent and responsible nature and behavior of citizens and benefit the community, nation, and state. One way to achieve this goal is to use an identity that is in a society in learning. The culture of each region will support the existence of national identity, and culture is one of the forms of community character.
\end{abstract}




\section{Pendahuluan}

Bangsa Indonesia memiliki suatu keanekaragaman budaya dengan segala keunikan dan penciri/ ciri khas yang berbeda satu dengan yang lainnya. Hal ini pula yang menjadikan bangsa ini menjadi suatu bangsa yang besar, beragam/berbhineka, serta berbeda dengan bangsa lainnya. Keberagaman yang dimiliki ini merupakan suatu unsur kebanggaan anak bangsa sekaligus suatu tantangan yang wajib untuk dipertahankan serta diwarisi kepada generasi selanjutnya. Akan tetapi seiring dengan perkembangan zaman yang ditandai dengan semakin derasnya arus globalisasi, perlahan budaya asli Indonesia sudah mulai terlupakan. Akibatnya adalah tidak jarang bangsa Indonesia kaum mudanya lebih memilih kebudayaan baru yang mungkin saja dinilainya lebih modern dibandingkan dengan budaya lokal.

Sejak munculnya penguatan dalam proses globalisasi pada akhir abad ke-20 dan memasuki abad ke- 21, konsep perubahan (change) adalah istilah yang sering diungkapkan berbagai kalangan dan kesempatan. Perubahan di sini telah menyentuh semua lapisan aspek kehidupan manusia, dalam bidang politik, ekonomi, sosial budaya, dan aspek kehidupan lainnya sampai pada konsep negara nasional atau negara bangsa (nation-state). Akibat kemajuan dalam ilmu pengetahuan dan teknologi (iptek) mengakibatkan batas negara secara ekonomi dan sosial budaya menjadi rancu dan samar. Semua ini kadang terbungkus dalam satu wadah yang disebut globalisasi. Status orang saat ini tidak hanya sebagai warga negara akan tetapi juga sebagai warga dunia/ global. Suatu hal yang mustahil kita dapat melakukan filtrasi atau menyaring segala bentuk pengaruh budaya melalui produk iptek.

Era Globalisasi juga telah mampu merubaha suatu tatanan dunia yang meliputi setiap sisi kehidupan di belahan dunia manapun dengan cepat dapat tersampaikan dan disaksikan oleh masyarakat dimanapun berada. Globalisasi membawa suatu dampak atau pengaruh positif dilihat dari aspek politik, seperti pemerintahan dijalankan secara terbuka dan demokratis. Dari aspek ekonomi, seperti terbukanya pasar internasional, meningkatkan kesempatan kerja dan meningkatkan devisa negara. Dari aspek sosial budaya, kita dapat meniru pola berpikir yang baik seperti etos kerja yang tinggi dan disiplin dan iptek dari bangsa lain yang sudah maju.

Namun demikian, globalisasi pun tidak lepas dari pengaruh negatif yang dibawanya dalam berbagai sisi kehidupan pula. Dari aspek ekonomi, hilangnya rasa cinta terhadap produk dalam negeri karena banyaknya produk luar negeri membanjiri Indonesia. Berbagai hasil sandang, papan dan barang-barang impor memenuhi pasar domestik tanpa peduli nasib para penghasil produk lokal yang kesusahan untuk bersaing dengan produk-produk impor tersebut. Aspek yang paling memprihatinkan akibat pengaruh dari globalisasi adalah kehidupan sosial budaya masyarakat yang selama ini dikenal sebagai komunitas tradisional yang hidup guyubrukun, sederhana, rajin, gotong-royong, dan religius. Masyarakat memperagakan individualis, krisis nilai-nilai kebangsaan, lebih mementingkan kepentingan individu atau golongannya dari pada untuk kepentingan Negara atau pemerintah.

Masyarakat Indonesia, berangsur telah berubah menjadi masyarakat konsumen dari arus barang-barang produksi dari negara-negara kapitalis, yang lazim dibeli secara kredit, bergaya hidup mewah yang penuh ditempeli atribut-atribut konsumtif dan hedonis. Impian masyarakat yang adil dan makmur seakan utopis di tengah sebagian besar masyarakat dilanda utang di counter-counter HP, developer perumahan, showroom motor dan mobil, toko elektronik, toko komputer, tempat pegadaian, bank-bank penyalur kredit, dan sebagainya. Kenyataan ini memperkuat betapa besarnya pengaruh iptek bagi kehidupan manusia. Kita tidak bisa mencegah atau menutup-tutupi mensterilkan diri dari pengaruhnya dari budaya asing. Barangkali solusi yang mampu dilakukan adalah memberi pengertian dan penjelasan bahwa terdapat dua pengaruh yang ada yakni positif dan negatif. Hal positif tentu akan bermanfaat dan perlu diserap, sedangkan hal yang negatif tidak perlu diserap dan perlu dihindari karena tidak memberikan manfaat kehidupan. Cara lai untuk membentengi generasi muda dengan ajaran agama, budi pekerti, akhlak, keteladanan, dan norma-norma lain yang baik. Perlu pula diperkenalkan norma hukum serta akibat-akibat pelanggaran terhadap norma tersebut.

Keinginan manusia untu membuat kehidupannya berjalan semakin cepat dan mudah dengan berbagai inovasi tentu juga menjadi alasan mendasar munculnya kreativitas dan inovasi 
yang terus berkembang. Hasil kemajuan iptek telah memberikan warna baru pada kehidupan masyarakat dewasa ini, perubahan secara struktur pola pikir, tata cara hidup, dan tentunya akan memberi warna baru pula dalam sosio-kultur yang terdapat pada suatu masyarakat. Akan muncul suatu perubahan kultur atau paradigma masyarakat dalam memandang diri dan kebudayaannya. Seperti kita ketahui bahwa salah satu unsur kehidupan manusia itu adalah kebudayaan/budayanya. Semakin manusia berbudaya maka semakin dia mampu mempertahankan kehidupan dalam segala bentuk persaingan di dalamnya.

\section{Hasil dan pembahasan}

1. Pancasila dalam globalisasi

Pancasila lahir dari sebuah perjanjian luhur berdasarkan suatu hasil musyawarah para pendiri bangsa dan negara Indonesia dalam sidang BPUPKI yang dilaksanakan selama dua kali masa persidangan yaitu pada 29 Mei - 1 Juni 1945 dan 10-16 Juni 1945. Presdiden Soekarno pada saat berpidato dalam sidang BPUPKI pada 1 Juni 1945 mengatakan mengenai pentingnya bangsa Indonesia memiliki sebuah "philosofiche gronslaag atau filosofi dasar yang memuat pandangan tentang dunia dan kehidupan. Hal ini merupakan suatu hal yang abadi yang harus tetap dijaga, tetap dipertahankan selama berdirinya negara. Oleh sebab itu perumusan dasar negara ini dilakukan melalui penggalian mendalam terhadap pandangan hidup dan falsafah hidup bangsa Indonesia yang mencerminkan nilai-nilai peradaban kebudayaan dan keluhuran budi yang mengakar dan tertanam dalam kehidupan bangsa Indonesia. Hal itu pula yang kemudian menjadi landasan dari lahirnya Pancasila sebagai dasar negara dan ideologi bangsa Indonesia.

Globalisasi sebagai fenomena arus global dalam peradaban manusia telah mentransformasi kehidupan masyarakat secara ekonomi maupun sosial budaya. Arus globalisasi yang terus berlangsung menyebabkan seseorang atau sekelompok orang maupun satu negara saling dihubungkan dan saling membutuhkan. Hal itu pulalah yang menyebabkan budayabudaya asing dapat dengan mudah masuk ke dalam suatu negara. Mudahnya masyarakat suatu bangsa menerima suatu budaya asing dalam kehidupannya, disebabkan karena unsur budaya asing tersebut membawa kemudahan bagi kehidupan masyarakat bangsa tersebut.

Pada umumnya, unsur budaya yang membawa perubahan sosial budaya dan mudah diterima masyarakat karena beberapa hal. Pertama, unsur kebudayaan tersebut membawa manfaat yang besar. Kedua, peralatan yang mudah dipakai dan memiliki manfaat. Ketiga, unsur kebudayaan yang mudah menyesuaikan dengan keadaan masyarakat yang menerima unsur tersebut. Karena sisi manfaat inilah, masyarakat suatu bangsa secara tidak sadar melupakan ideologi negaranya. Derasnya pengaruh nilai-nilai budaya global, tentu saja menimbulkan masalah-masalah sosial, seperti semakin tajamnya kesenjangan sosial yang dapat menimbulkan timbul kecemburuan sosial, menajamnya konflik rasial, memudarnya nilai-nilai budaya asli dan sebagainya.

Bagi bangsa Indonesia, derasnya pengaruh nilai-nilai budaya global mengaburkan keberadaan Pancasila sebagai ideologi, falsafah hidup bangsa dan dasar negara. Budaya yang cenderung mengedepankan demokrasi, namun masih kurang mengedepankan sikap dan perilaku yang toleran. Akibatnya, sebagai bangsa yang majemuk, kebhinekaan Indonesia terus diuji dengan berbagai peristiwa kekerasan, kerusuhan yang berbau SARA. Masyarakat mulai lupa akan identitas diri sebagai bangsa Indonesia, sehingga tidak menutup kemungkinan mengubah arah ideologi Pancasila. Jika hal tesebut terjadi maka rasa nasionalisme bangsa akan hilang. Di tengah pusaran arus globalisasi dunia, bangsa dan negara Indonesia tak mesti kehilangan jati diri, kendati hidup di tengah-tengah pergaulan dunia. Rakyat yang tumbuh di atas kepribadian bangsa asing mungkin saja mendatangkan kemajuan, tetapi kemajuan tersebut akan membuat rakyat tersebut menjadi asing dengan dirinya sendiri. Mereka kehilangan jati diri yang sebenarnya sudah jelas tergambar dari nilai-nilai luhur Pancasila. Di era globalisasi ini peran Pancasila tentulah sangat penting untuk tetap menjaga eksistensi kepribadian bangsa Indonesia.

Namun demikian, diperlukan suatu pengawasan dalam mengaudit berbagai peraturan perundang-undangan mulai dari UU sampai ke peraturan paling rendah. Saat ini belum ada 
mekanisme dan kelembagaan yang berfungsi sebagai pengawasan eksekutif (executive review) yang secara khusus diberi tugas untuk memasyarakatkan dan mengawasi pelaksanaan Pancasila dan UUD 1945 sebagaimana mestinya. Mekanisme yang ada hanya pengawasan hukum melalui peradilan (judicial review) baik melalui Mahkamah Konstitusi untuk pengujian undang-undang maupun melalui Mahkamah Agung untuk pengujian peraturan di bawah undang-undang.

Saat ini telah timbul beberapa persoalan yang mencerminkan krisis identitas bangsa, antara lain: Pertama, Menurunnya penghayatan terhadap nilai-nilai Pancasila. Kedua, Euforia demokrasi yang kebablasan. Dalih "Demokrasi" telah membawa berbagai tindakan yang justru menimbulkan keresahan, unjuk rasa kerap diwarnai perusakan berbagai fasilitas publik, aksi brutal main hakim sendiri hingga konflik yang menimbulkan korban jiwa sering kita saksikan di berbagai media massa. Keamanan, ketertiban dan kepatuhan terhadap rambu-rambu hukum pun menjadi terancam. Atas nama keadilan, demokrasi dan HAM, berbagai rambu-rambu hukum dilanggar. Bahkan ekses dari demokratisasi kerapkali diwarnai dengan berbagai konflik kekerasan. Ketiga, daya perekat (Kohesi) sosial masyarakat menurun sehingga rentan konflik bernuansa kekerasan.

Realitas kehidupan sosial masyarakat dalam keberagaman sering diwarnai berbagai letupan konflik yang berlatar belakang mayoritas-minoritas, pribumi-pendatang, perbedaan suku maupun agama. Tatkala bangsa kita masih menganggap mayoritas adalah prioritas, penghormatan terhadap keberagaman itu sendiri takkan pernah terjadi. Seringkali pula masih ditemukan adanya kecurigaan atau kesinisan dari kelompok yang sudah lebih dulu tinggal dan menetap terhadap pendatang.

Keempat, kesenjangan yang memicu kecemburuan sosial. Era global tidak saja membawa letupan-letupan konflik akibat ekses budaya, tapi dilatarbelakangi pula pada distribusi ekonomi yang tidak merata. Kesenjangan antar-kelompok masyarakat dalam bidang ekonomi, pendapatan per kapita, kesempatan memperoleh pendidikan, perbedaan dalam mengakses fasilitas pemerintah, telah memicu kecemburuan sosial. Persoalan-persoalan tersebut menimbulkan prasangka atau kontroversi hingga berakhir dengan konflik yang berbuah kekerasan.

\section{Kepentingan Politik dan Krisis Keteladanan}

Masyarakat seringkali mengajukan tuntutan kepada pemerintah dan jika tidak dipenuhi, masyarakat cenderung bertindak anarkis yang menimbulkan korban jiwa dan materi. Ketidakpuasan satu kelompok terhadap kelompok yang lain diekspresikan dalam bentuk penggalangan massa secara kolosal untuk pamer kekuatan dan melakukan tindakan anarkis. Tidak jarang pula elit menggunakan emosi rakyat sebagai alat untuk memaksakan kehendak mereka. Kerap emosi-emosi tersebut ditunggangi elit-elit tertentu sebagai alat mencapai kepentingan tertentu. Sebagai contoh ketidakteladanan sebagai tontonan konsumsi public yakni kasus yang menjerat pejabat pemerintahan maupun elit partai pada setiap level elit. Minimnya keteladanan ini menyebabkan rakyat apatis dan menimbulkan ketidakpercayaan terhadap pemerintah.

Budaya politik yang mengedepankan demokrasi namun masih kurang mengedepankan sikap dan perilaku yang tidak etis, masih mengedepankan ego kelompok atau golongan daripada kepentingan nasional. Tarik-menarik kepentingan partai baik dilatari oleh berbagai agenda sesaat maupun dalam rangka pemenangan pemilihan kepala- kepala daerah dan perwakilan yang akan duduk di lembaga legislatif. Praktek politik pun berlanjut ketika mereka menempati jabatan-jabatan politik baik di pemerintahan maupun di legislatif. Hal ini dapat dilihat dari sangat kuatnya pengaruh kepentingan kelompok atau partai dalam proses perumusan perundang-undangan yang mengatur kehidupan kemasyarakatan di segala bidang. Proses tersebut dapat diamati dalam penyusunan Program Legislasi Nasional (Prolegnas), lebih banyak didominasi oleh kepentingan-kepentingan politis bersifat pragmatis daripada cita-cita membangun suatu sistem hukum yang memiliki jiwa dan karakter ke-Indonesia-an untuk mendukung pencapaian tujuan hidup berbangsa dan bernegara.Berbagai produk UU dan perubahan-perubahannya belum mampu sepenuhnya dirasakan membawa keadilan bagi 
seluruh rakyat. Karena perubahan-perubahan tersebut sarat akan kepentingan kelompok/ golongan dari pada kepentingan nasional.

Situasi tersebut kemudian mengalami komplikasi dengan permasalahan etika politik yang rawan manipulasi, akuntabilitas politik yang rendah, permasalahan korupsi yang terdapat pada lembaga-lembaga penting penyelenggaraan negara. Para petualang politik pun mencaricari momentum yang tepat bagi mereka untuk nimbrung dalam kekisruhan politik demi mendapatkan keuntungan dalam situasi tersebut. Kondisi demikian memperlihatkan terabaikannya etika politik yang diharapkan mampu menjinakkan perebutan kekuasaan. Etika politik gagal mengatur kepentingan-kepentingan kelompok dengan membangun institusiinstitusi yang lebih adil terutama dalam membangun sistem demokrasi yang sehat dan subtansial.

Berbagai peristiwa di tingkat elit menjalar dan ikut mempengaruhi sosial politik di daerah, membawa masyarakat kepada krisis figur elite politik yang dapat menjadi patron masyarakat. Akibatnya, kelompok- kelompok masyarakat mulai dari rakyat biasa, partai politik, lembaga swadaya masyarakat, kelompok agama, golongan dan lain sebagainya terbiasa dan cenderung berpikir untuk kelompok atau golongannya sendiri tanpa memperhatikan kepentingan yang lebih besar. Berbagai peristiwa tidaklah berdiri sendiri, tetapi memiliki resonansi, yang saling berkaitan, memberikan pengaruh dan ikut menggetarkan tatanan kehidupan bermasyarakat dan bernegara. Resonansi ini dapat diamati dari peristiwa yang terjadi di bangsa ini maupun dalam kehidupan global yang cepat merambat ke berbagai pelosok kehidupan masyarakat melalui perkembangan media. Kecepatan informasi global, media sosial, regulasi di bidang komunikasi, kebebasan akses situs, alat politik, bahkan menjadi alat propaganda dan berbagai tindak kekerasan dan gejolak sosial di suatu daerah.

\section{Semangat Kebangsaan dan Keteladanan}

Masalah kebangsaan tidak cukup dengan menggunakan akal dan logika tetapi juga hati. Kejujuran, nafas spiritual, empati dan nilai-nilai kebaikan hendaknya terpelihara dan mengisi kultur sosial kehidupan bermasyarakat, berbangsa dan bernegara kita. Nilai-nilai kebangsaan sangat penting yang tidak sekedar mengingatkan kita akan sejarah berdirinya NKRI. Negara ini tidak dibangun dalam sehari tetapi memakan usia dan mengurai darah, airmata. Apa yang menjadi sejarah perjalanan bangsa ini tidak cukup dengan peringatan seremonial pada momentum satu waktu tertentu, tetapi pengorbanan jiwa dan raga di masa lalu harus mampu membangkitkan generasi masa kini dan akan datang, menginspirasi, mengembangkan dan memelihara semangat kebangsaan, serta hasrat mewujudkan cita-cita menuju bangsa yang makmur.

Elite pemerintah maupun pejabat negara mempunyai tugas yang tidak ringan karena berkewajiban untuk menciptakan kesatuan dan rasa kebersamaan yang merupakan dasar pokok bagi terwujudnya suatu nation and state building yang kokoh. Bangsa ini memerlukan keteladanan dalam setiap sikap dan perilaku dari para penyelenggara negara, baik pejabat negara yang menjalankan fungsi eksekutif, legislatif, maupun yudikatif. Aparatur pengelenggara negara dan pemerintahan tidak menyalahgunakan kekuasaan dan kewenangannya dan harus selalu memastikan tidak adanya penyimpangan dalam pelaksanaan dan penegakan hukum (law in action). Meningkatkan fungsi pelayanan masyarakat, profesional, taat hukum, berdaya guna, produktif, transparan, bebas dari KKN.

Seluruh elemen bangsa bersikap peka dan turut dalam kehidupan politik dan pemerintahan negara yang bersifat konstruktif, atas dasar persamaan tanggung jawab sesuai dengan peran dan kedudukannya masing-masing. Dalam membangun semangat kebangsaan memerlukan role yang dapat menjadi panutan dalam kehidupan masyarakat. Pertama, para elit di lembaga pemerintah maupun legislatif mengedepankan visi kebangsaan yang tercermin dari setiap sikap dan perilakunya di tengah masyarakat, mengedepankan kepentingan bangsa daripada kepentingan golongan dan partai demi kokohnya ketahanan nasional. Kedua, partai politik senantiasa memberikan pemahaman nilai- nilai demokratisasi kepada masyarakat dengan mengedepankan rasa nasionalisme daripada kepentingan sempit yang merusak harmoni kerukunan masyarakat. Ketiga, peran pejabat pemerintahan senantiasa memiliki sense of crisis 
(rasa peka terhadap krisis yang terjadi). Kepekaan terhadap perubahan dan kemampuan analisa dampaknya. Kepedulian terhadap rakyat yang mengalami kesulitan ekonomi tercermin dalam kebijakan maupun dalam tindakan nyata dari setiap para pejabat pemerintahan. Keempat, peran pejabat pemerintahan dalam membangun komunikasi publik. Ruang komunikasi publik yang disediakan mampu mengoptimalkan partisipasi masyarakat dalam penyelenggaraan negara.

Pikiran jernih akan melahirkan keinginan yang baik. Keinginan yang baik akan lahirkan pilihan yang baik. Pilihan-pilihan yang baik akan lahirkan kebiasaan-kebiasaan yang baik. Kebiasaan yang baik akan menciptakan situasi yang baik. Situasi yang baik akan merajut masa depan yang baik. Optimis dan senantiasa bersyukur atas segala sesuatu yang telah kita miliki. Hidup bukan hanya selalu mengambil dan mempunyai, tetapi hidup juga untuk memberi dan berbagi. Dengan demikian, proses reformasi dan transformasi character building mengarah pada terbentuknya spirit nasionalisme yang tinggi, rasional dan obyektif, akuntabel, demokratispopulis, menjunjung tinggi supremasi hukum, serta etis profesional.

\section{Cerminan Nilai-Nilai Pancasila}

Demokrasi yang dikehendaki sebagai pilihan sistem pemerintahan Indonesia adalah demokrasi yang selaras dengan nilai-nilai Pancasila dan karakter bangsa Indonesia. Namun dalam perjalanan sistem demokrasi Pancasila lebih banyak diucapkan dalam ruang-ruang seminar daripada tercermin dalam semangat kebangsaan, sehingga yang terwujud adalah kebebasan atas nama demokrasi tapi bias berbagai kepentingan politik. Saat ini pemahaman masyarakat terhadap nilai-nilai Pancasila menjadi relatif kurang memenuhi harapan. Kondisi ini tidak lepas dari penerapan Pancasila sebagai ideologi negara selama orde baru terkesan digunakan sebagai salah satu alat untuk mempertahankan kekuasan. Pasca reformasi, tiba-tiba konflik kesukubangsaan, agama, pelapisan masyarakat mengusik kerukunan berbangsa dan bernegara. Ibarat panas setahun dihapuskan hujan sehari.

Globalisasi pun mendapatkan jalan mulus dalam mengisi kehidupan bermasyarakat dan berbangsa. Semacam muncul stimulus perubah kepribadian pelbagai pihak dalam waktu sekejap. Para pemburu kekuasaan pun menjadikannya senjata dalam berseteru, meraup aset dan pengaruh. Pada situasi seperti ini sebaiknya semua pihak harus kembali memegang teguh nilai-nilai luhur Pancasila. Sampai kini bangsa Indonesia masih tetap utuh dan bersatu, hal ini membuktikan bahwa nilai-nilai luhur yang terkandung di dalam Pancasila telah ada sejak dahulu kala dan melekat dalam kehidupan berbangsa dan bernegara.

Peran Pancasila sebagai pandangan hidup dan dasar negara memegang peranan penting. Pancasila menjadi filter nilai-nilai mana saja yang bisa diserap untuk disesuaikan dengan nilai-nilai Pancasila sendiri. Dengan begitu, nilai-nilai baru yang berkembang nantinya tetap berada di atas kepribadian bangsa Indonesia. Pasalnya, setiap bangsa di dunia sangat memerlukan pandangan hidup agar mampu berdiri kokoh dan mengetahui dengan jelas arah dan tujuan yang hendak dicapai. Dengan pandangan hidup, suatu bangsa mempunyai pedoman dalam memandang setiap persoalan yang dihadapi serta mencari solusi dari persoalan tersebut. Dengan pemahaman terhadap ideologi Pancasila, keberagaman dalam kehidupan sosial budaya masyarakat Indonesia baik dari segi ras, etnis, budaya, bahasa, dan agama, tidak menjadikan bangsa ini tercerai-berai, akan tetapi justru merupakan kekuatan bangsa dan Negara Indonesia di tengah pergaulan dunia.

Meskipun konstitusi Indonesia telah mengalami amandemen sebanyak empat kali, MPR memutuskan untuk mempertahankan bagian pembukaan (Preambule) yang memuat dasar negara. Keputusan untuk mempertahankan pembukaan UUD 1945 adalah penegasan terhadap kokohnya ideologi negara yang berdasarkan Pancasila. Keputusan tersebut seharusnya tidak berhenti pada upaya mempertahankan landasan konstitusi tersebut, tetapi diperlukan langkah-langkah selanjutnya agar berbagai produk perundang-undangan yang lahir terhindar dari kepentingan-kepentingan politis bersifat pragmatis. Oleh karena itu, harus ada grand design yang jelas terhadap berbagai produk hukum yangberlandaskan dan dijiwai oleh norma dasar (grund norm) landasan ideal Pancasila dan UUD. 
Oleh karena itu, diperlukan suatu lembaga pengawasan eksekutif (executive review) sehingga Pancasila dan UUD 1945 tercermin dan terjabarkan dalam berbagai norma hukum yang tertuang dalam berbagai peraturan perundang-undangan mulai dari UU sampai ke peraturan paling rendah. Lembaga baru tersebut tidak hanya diberi tugas pengkajian, koordinasi pendidikan, dan pemasyarakatan Pancasila dan UUD 1945, tetapi juga diberi kedudukan hukum (legal standing) untuk mengajukan pengujian konstitusionalitas dan legalitas atas undangundang dan peraturan di bawah undang-undang terhadap norma hukum yang lebih tinggi berdasarkan nilai-nilai Pancasila dan UUD 1945. Agar Pancasila dan UUD tercermin pada setiap produk hukum, maka para pembuat peraturan perundang-undangan dan pelaksana dituntut untuk tidak hanya harus cerdas, memiliki pengetahuan yang dalam dan luas, serta bijaksana, tetapi juga harus memiliki kesadaran konstitusional (constitutional awareness) dan kepekaan konstitusional (constitutional sensitivity).

\section{Simpulan dan saran}

Pergaulan dunia yang damai dan bermartabat, sebagaimana digagas para pendiri Bangsa Indonesia memerlukan dukungan bukti dalam implementasi Pancasila secara konsisten dalam penyelenggaraan pemerintahan Negara. Pancasila akan senantiasa menjadi inspirasi dalam tiap aspek kehidupan berbangsa dan bernegara, termasuk dalam perumusan berbagai peraturan perundang-undangan. Dengan demikian, Negara Indonesia memiliki landasan moralitas dan haluan kebangsaan yang jelas dan visioner. Suatu pangkal tolak dan tujuan pengharapan yang penting bagi keberlangsungan dan kejayaan bangsa.

Dengan landasan pijak yang kokoh dan karakter kepribadian dan spirit yang kuat maka tidak akan mudah terombang-ambing dalam deras arus globalisasi dan dipengaruhi oleh sistem hukum dari luar yang memiliki karakter kepribadiannya sendiri dengan kepentingannya sendiri. Oleh karena itu, penyelenggara negara wajib untuk memelihara budi pekerti kemanusiaan yang luhur dan memegang teguh cita-cita moral rakyat yang luhur sebagaimana ditandaskan dalam penjelasan umum UUD 1945. Dengan keteladanan para pemimpin akan mempengaruhi budaya masyarakat yang pada akhirnya akan memantapkan karakter bangsa.

Pada akhirnya diharapkan seluruh elemen bangsa bersikap peka dan turut dalam kehidupan politik dan pemerintahan negara yang bersifat konstruktif, atas dasar persamaan tanggung jawab sesuai dengan peran dan kedudukannya masing-masing. Sebagai kalimat penutup, "Mari kita menyongsong Indonesia yang lebih baik dengan sentuhan wawasan kebangsaan di setiap profesi."

\section{Daftar Rujukan}

Abdul Azis Wahab, Sapriya. 2011. Teori dan Landasan Pendidikan Kewarganegaraan. Bandung: Alfabeta.

Ahmadi, Koiru. 2012. Mengembangkan Pendidikan Berbasis Keunggulan Lokal Dalam KTSP. Jakarta: Prestasi Pustaka.

Febriansyah, Ferry Irawan. 2012. Muatan Kepentingan Politik Penentu Kualitas Undang-Undang. Perspektif, 17(3).

Latif, Yudi. 2011. Negara Paripurna: Historitas, Rasionalitas dan Aktualitas Pancasila. Jakarta: Gramedia Pustaka Utama.

Pranata, Dewa. 2017. Ngayah Tak Sekedar Mayah, https;//dewapranata. Diakses pada 17 November 2017.

Sapriya, dkk. 2014. Konsep Dasar Pendidikan Kewarganegaraan, Lab. Pendidikan Kewarganegaraan UPI, Bandung.

Solihatin, Etin. 2012. Strategi Pembelajaran PPKn. Jakarta: PT. Bumi Aksara.

Suja, Wayan. 2010. Kearifan Lokal Sains Bali. Denpasar: Paramita.

Trisna, Mahardika, Cecep Darmawan. 2016. Civic Culture Dalam Nilai-Nilai Budaya dan Kearifan Lokal Masyarakat Bali Aga Desa Trunyan. Humanika, 23(2). 